Information for citation:

Golovina, S. Yu., Ivanchina, Yu. V. (2021) The Social Value of Labour Law through the Prism of Needs of an Individual and Society. European and Asian Law Review. 4 (1), 36-45. DOI: 10.34076/27821668_2021_4_1_36.

UDC 349.2, 331.1

BISAC LAW054000

DOI: 10.34076/27821668_2021_4_1_36

Research Article

\title{
THE SOCIAL VALUE OF LABOUR LAW THROUGH THE PRISM OF NEEDS OF AN INDIVIDUAL AND SOCIETY
}

\author{
SVETLANA YU. GOLOVINA \\ Ural State Law University \\ ORCID ID: 0000-0003-3987-121X \\ YULIA V. IVANCHINA \\ Ural State Law University \\ ORCID ID: 0000-0001-9306-2216
}

This article raises and justifies a thesis on the social value of labour law as an independent branch of law. The authors conclude that the social value of labour law arises from the fact that it is based on a triad of social values that are of key significance for the development of civilization development. The first element of the triad is labour since it represents the material basis for the development of society and the foundation for any civilization. Labour, as an activity aimed at meeting the needs of the individual and society, is an essential condition for human life and determines its quality. The second element is law as an institution of civilization: it is the mechanism for implementing requirements that ensure the "self-preservation" and development of society. Because the law is a social regulator, it not only ensures that society as a whole functions normally, but it also ensures the safety of an individual in society, as well as fundamental rights and freedoms. The third element is socially significant needs, which cannot be satisfied without entering into public relationships regulated by laws. Based on the theory of the hierarchy of needs and motivation of human activity, the analysis of international normative instruments upholding basic human rights and freedoms, the authors conclude that labour law as the independent branch of law possesses social value and maintains it in current conditions. This conclusion is based on the fact that for the overwhelming majority of the working population, satisfaction of basic needs (physiological and safety needs) necessary to sustain livelihood is possible precisely through entering into labour relationships. At the same time, labour law affects the rate of state economic development, and its regulations have an impact, both directly and indirectly, on the creation and support of public peace in society. This confirms the thesis on the social value of labour law.

Key words: labour, labour law, needs, social value, quality of work life, employee, employer

\section{Introduction}

Ongoing social and economic changes associated with both accelerated digitalization and spread of the new coronavirus infection have affected the legal system, which had no choice but to respond to these changes. Thus, many concepts, categories and their content must be reexamined.

Conducting research in the most important and promising areas remains one of the main tasks facing the academic legal community. This may include identifying the essence and social purpose of labour law, 


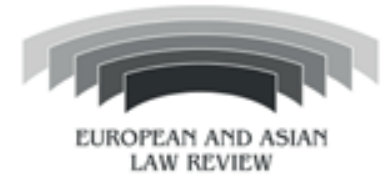

Vol 4. Is. 1

as well as analysing its functions in today's conditions. Without an understanding of the objective of legal regulations and how they affect the public relationships mediated by this branch of law, forming effective labour legislation that responds to the challenges of the present situation is impossible.

At the same time, an answer to the question on the social value of labour law for today's society is critical. Specifically, 'the category of social value makes possible to highlight the phenomenon more broadly, in a new light, and characterize it not only as inevitable, but also as a social good that can make a difference, bring positive results and a gain in social life ('revive' objects and phenomena)' (Alekseev, 2019: 6).

This issue is of particular importance at present since many social values are now facing serious challenges. As E.V. Berezovskaya justly noted that this issue is a result of the destruction of traditional value system and the adoption of values unusual for our society, as well as the formation of new values in the context of developing market relations. It should be kept in mind that values play an important role in the life of society and of an individual, consolidate society and all its members, they are a major factor in its stability and positive development, and the condition for its vitality (Berezovskaya, 2013: 84).

Labour law appears to be one of the most significant civilizational accomplishments that have social value. Thus, 'the history of humankind embodied in the history of ancient and modern civilizations is the history of human labour, since no other being in the world, except a human, is capable of conscious activity to create artificial conditions for life' (Martseva, 2002: 17). It is labour that is the basis for material, technical and moral accomplishments of humankind in the course of civilization's development.

Research devoted to labour spans the entire history of social thought. Plato once noted that workers who bear the brunt of physical labour provide the material conditions for the entire society's existence (2015: 10). Labour is explicitly recognised as a material and technical foundation for the development of society and a foundation for any civilization. Labour is an essential condition for human life. Moreover, labour is an inherent characteristic of any person.

Economists have attached great importance to the category of labour, especially in its impact on economic development. For example, Adam Smith, who developed the concept of division of labour, in his work 'An Inquiry into the Nature and Causes of the Wealth of Nations' points out that labour produces wealth in every country. However, all labour weighted equally may not be equally productive - the greatest increase in productivity is due to the division of labour (1908: 13).

Later, the study of labour split into different directions - in addition to labour economics, there is philosophy of labour, sociology of labour, psychology of labour and others. According to N.N. Nikiforova, labour is the basic social pattern of the community, since this pattern is formed and reproduced in labour, while in other areas of life this social pattern is only manifested (1983: 75). This confirms the thesis that labour in all its forms represents the social value for society.

However, not all labour is subject to legal regulation. Only labour that relates to the socially significant needs of society needs to be regulated. As E.B. Khoklov accurately notes, since labour is an inherent characteristic of the individual and society, it is clear that to the extent that labour has manifested itself in a social environment, it has been subjected to social impact, including, of course, legal regulation (2013, I: 6).

Any society requires regulatory mechanisms that ensure its stability and ability to develop itself. Law, as an institution of civilization, has become a mechanism for implementing requirements which provide the 'self-preservation' and the society development.

It seems that law, along with labour, possesses the highest social value. Since law is a social regulator, it not only ensures that the entire society functions normally, but it also ensures the safety of an individual in society and guarantees fundamental rights and freedoms.

The social value of law, according to E.V. Berezovskaya, is a characteristic of law that is expressed in its necessity, usefulness and the achievement of only a positive result, making law a distinct object of reality, also the properties of law that result from its interaction with public needs and interests, and in satisfying the latter (2013: 85).

Yet, paradoxically, the entire, huge statutory world starts from one simple point - the satisfaction of physical and spiritual needs (Maltsev, 2011: 247). G. Hegel once noted: 'Taking a closer look at history, we are convinced that all actions made by people are preconditioned by their needs' (1928: 73). 'The concept of need is one of the fundamental categories of social science. Not a single area of modern public knowledge is complete without this concept. Economics, sociology, demography, management 
theory - these all appeal to human needs, and each of the branches of knowledge sees its own aspect in this category ... The theory of needs, developed by the founders of Marxism, has methodological significance for other social sciences, and each of these sciences explores the problem of needs from its own standpoint' (Zdravomyslov, 1977: 6, 10).

In agreeing with the position set forth by D. A. Kerimov, who believes that needs are "no less important for legal science because only if there is an objective commonality in the system of the needs of individuals ... can law arise, exist and act as a specific tool that contributes to the satisfaction of their vital needs' (1972: 118), we also note that not all the needs of society become a basis for its legal affairs. It is primarily socially significant needs that are satisfied through provisions of law. Thus, only those needs should be recognized that are necessary for the existence of the individual, social groups and society as a whole, and whose satisfaction is impossible on their own.

Socially significant needs represent a set of distinct, stable (typical) needs required to improve living conditions, benefits necessary for the preservation and development of an individual, social groups and society as a whole, which cannot be satisfied without entering into social relations and enshrining them in the law. The set of needs will vary according to the branch of law.

It is well-known that the subject of labour law is labour and other directly connected relationships, which, in fact, are represented by socially significant needs of its parties. The essence of these needs is very accurately depicted by R. Ihering: the main point is that 'the employee exchanges money for labour, the employer - labour for money; what they get, for both of them, is more necessary than what they have' (1881, I: 54).

The above confirms the thesis that labour law as an independent branch of law possesses social value and maintains it even in light of transformational processes currently taking place in society and economy. This is preconditioned by the triad of social values at its base (labour, law, needs), which allowed society to proceed from the barbarism stage to civilizational development.

The main component in this triad is socially significant needs, which for the most of working population can be satisfied only by entering into labour relationships, which must be properly regulated by the state.

The main purpose of this study is to substantiate and confirm the thesis on the social value of labour law based on the theory of social needs, as well as its role in the development of modern society. This is achieved by solving several interrelated tasks, in particular, by analysing the role of socially significant needs in the effective legal regulation of labour relationships.

\section{Materials and methods}

The authors used the dialectical method applied to the consideration of the tasks identified through general scientific (analysis, synthesis, formal-logical approach) and special scientific (legal interpretation) research methods of legal phenomena, as well as the method of moving from abstract to concrete. The study is based on the system of philosophical knowledge formulating basic requirements for scientific theories and verifying the essence of phenomena in question.

\section{Results}

The results of the study are given in the conclusions.

\section{Discussion}

L. S. Yavich believed that law is dictated by objective needs of social progress, nature of production relations and man's social nature (1985: 13).

Human needs and labour have always been the integral part of social life, since a need is the demand of a person for something, comprehended by him and determining his purposeful activity. The social meaning of human needs is expressed in the fact that the needs of people are the main driving force of societal development, since their satisfaction is associated with the elaboration of new methods for production and consumption of the finished product (Chinkin, 2010: 7-10).

The deeper understanding of what and under what circumstances prompts a person to work, including actors of labour law, can be reached using one of the most popular and well-known theories - the theory 
of the hierarchy of needs and motivation of human activity, developed by A. Maslow, better known as the needs pyramid.

According to this theory, human needs can be reflected in an ascending scale. A. Maslow identified the following levels of needs: physiological needs; safety needs; needs for love and belonging; needs for esteem, cognition; aesthetic needs and need for self-actualization (Maslow, 2008).

One of the conclusions reached by A. Maslow and giving answers to many questions related to needs, is expressed as follows: physiological needs dominate all others. If a person needs food, safety, love and esteem at the same time, then he or she will desire food more than anything else. When physiological needs are dominating, all the others simply cease to exist or are overshadowed. At the same time, if the body is relieved of the dominance of physiological needs, provided that they are in a constantly satisfied state, ceasing to exist as active determinants and being merely a potential capacity, it becomes possible to express other, social needs and goals of a higher level (2008: 61-63). However, all needs should be considered as social, regardless of their level in the hierarchy.

The qualitative transformation of needs means that even main needs are not biological in the full sense of this word. The biological basis is found only in the very initial stimulus; but the direction of the need itself, its content and, moreover, the ways of satisfaction are determined by social relations and specific forms of human livelihood. Therefore, the initial needs of a person are social in their nature (Zdravomyslov, 1977: 7).

'Need is a thread through which nature attracts a person to society' (Ihering, 1881, I: 78). Moreover, 'each of us as an individual needs certain means to maintain our existence, whether material or spiritual. To obtain these means, we use known efforts and carry out work' (Ozerov, 1904, I: 51). Specifically, the yearning to satisfy natural needs more substantially encourages people to work continuously.

Labour as a social value, in terms of its definition, is a rather broad category. G. E. Slezinger offers his own definition of the concept: 'Labour is a purposeful human activity, in the process of which he/she modifies and adapts natural objects to meet needs of each individual and the society as a whole - it forms not only the society, but also a person, encourages him/her to acquire knowledge and professional skills, interact with other people, make the needs more complicated' (1996: 13). This interpretation leads to an important conclusion: the social value of labour is not only that it leads to the satisfaction of needs, but also forms society and the individual, and, moreover, generates new needs. Thus, during the fourth industrial revolution, the need for additional professional education for workers and their higher labour mobility has sharply increased, and the state immediately responded by adopting a number of program documents ${ }^{1}$. Global experience shows that the professional mobility and competitiveness of specialists should be based on the idea of continuous professional education throughout their work life, as provided for under Art. 4 of Human Resources Development Convention, 1975 (No. 142) ratified by the USSR ${ }^{2}$. Incidentally, the international community considers vocational education as one of the most important components of the Decent Work Concept (Khudyakova, Bryukhina \& Novikova, 2011: 66-95).

Since its appearance, hired labour has been one of the most favourable ways to satisfy needs, since labour relationships are lasting by nature and provide regular income. According to G. Hegel, only 'hard human effort and labour can provide means to satisfy human needs' (1934, VII: 222). For example, in today's conditions, the need for food, accommodation and clothes can hardly be satisfied without the opportunity to work and earn money.

For regular satisfaction basic (physiological) and safety-oriented needs in most cases material resources (money) are required. Today, as before, for the most working population the main and stable source of income and livelihood opportunities (satisfaction of basic needs) is still the salary received for work under an employment contract. Thus, it can be concluded that labour relations are optimal for meeting basic needs.

\footnotetext{
${ }^{1}$ Resolution of the Government of the Russian Federation No. 298 of April 15, 2014 'On Approval of the State Program of the Russian Federation 'Promotion of Population Employment'; Order of the Government of the Russian Federation No. 663-r of April 24, 2014 'On Action Plan for Increasing Mobility of Citizens of the Russian Federation for 2014-2018'; Decree of the President of the Russian Federation No. 622 of October 31, 2018 'On Concept of State Migration Policy of the Russian Federation for 2019-2025', and etc.

${ }^{2}$ International Labour Office (1991) Conventions and Recommendations 1957-1990. Vol. II. Geneva, International Labor Conference, pp. 1751-1754.
} 
The socially significant needs of an employee as an actor of labour law should include the opportunity to work and earn money, providing a livelihood for himself/herself and the family, as well as to perform work in decent conditions. This conclusion is based not only on A. Maslow's theory of needs, according to which this is what allows the employee to satisfy basic needs (physiological and safety-oriented needs). The aggregate of socially significant needs was recognized by the world community a long time ago and reflected in the list of basic human rights. Despite the diversity of fundamental rights, rights at work constitute the foundation without which labour cannot bring any social value to the society.

Thus, the International Covenant on Economic, Social and Cultural Rights ${ }^{3}$ enshrines the right to work, which includes not only the right of everyone to the opportunity to gain a living by work which he/she freely chooses or accepts, but also the right to full and productive employment (Art. 6). Article 1 of the European Social Charter ${ }^{4}$ provides for the realization of the right to work, taking into account the provision of a high and stable level of employment, as well as the right to earn a living in an occupation freely entered upon. The norm specified in Art. 23 of the Universal Declaration of Human Rights seems to be close to this in content ${ }^{5}$, saying that everyone who works has the right to just and favourable remuneration ensuring for himself an existence worthy of human dignity.

Exercising the right to work endows an individual with elements of human dignity, and the opportunity to receive remuneration for work is an important component of ensuring a decent standard of living (Smith, 2013: 315) and forming the basis for manifesting higher level social needs (aesthetic needs, the need for self-actualization).

However, an employee entering labour relationships experiences other needs, which are also reflected in international labour standards. These include the need to create decent, including safe and healthy, working conditions.

Such a conclusion is made based on Art. 7 of the International Covenant on Economic, Social and Cultural Rights, which recognizes the right of everyone to the enjoyment of just and favourable conditions of work which ensure, in particular: working conditions that meet safety and hygiene requirements; rest, leisure, reasonable limitation of working hours and periodic holidays with pay, as well as remuneration for public holidays, etc. The European Social Charter also includes the right of everyone to reasonable daily and weekly working hours, public holidays with pay, provision for a minimum of four weeks' annual holiday with pay, elimination of risks in inherently dangerous or unhealthy occupations, etc. (Art. 2). Article 3 enshrines the right to occupational security and health protection, so that the working conditions would meet safety and hygiene requirements.

It should be noted that national labour legislation is also aimed at fulfilling these needs of employees. In this connection, Art. 2 of the Labour Code of the Russian Federation ${ }^{6}$ includes, as the fundamental principles, the right of every employee to fair working conditions, timely payment of wages in full, ensuring a decent human existence for both the employee and the employee's family.

Consequently, employees not only feel the need to provide a livelihood for themselves and their families, but to do this by entering into a lasting labour relationship that ensures stable and full-time work. In addition, people have a need to ensure that such an opportunity is guaranteed to them, and they have decent working conditions, since one of the basic vital needs of a person, without which, as already noted, a livelihood is impossible or extremely difficult, is the need for material resources (money). We can say that money, which is manifested in labour relationships as wages, in the modern world makes it possible to satisfy most human needs, not only physiological, but also social, spiritual, aesthetic, etc. A stable income serves as a guarantee of the safety and health of the employee and family, providing a sense of confidence in the future.

A. Maslow pointed out that the need for safety is expressed in the desire to get a permanent job with guaranteed protection, in striving to have a savings bank account and various types of insurance (health, unemployment, disability, old-age insurance) (2008: 63-64).

We believe that it is the labour law that can satisfy the specified set of socially important needs to the maximum possible extent. Even the right to health protection and a pension is closely related to

\footnotetext{
${ }^{3}$ United Nations (1966) International Covenant on Economic, Social and Cultural Rights. New York, the General Assembly of the United Nations.

${ }^{4}$ Council of Europe (1996) European Social Charter. Strasbourg.

${ }^{5}$ United Nations (1948) Universal Declaration of Human Rights. Paris, the General Assembly of the United Nations.

${ }^{6}$ The Labor Code of the Russian Federation (Federal Law No. 197-FZ of December 30, 2001).
} 


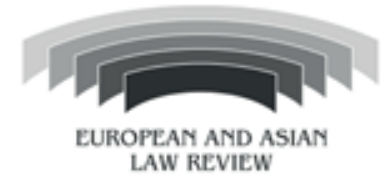

Vol 4. Is. 1

the implementation of labour relationships; it is no coincidence that legal relationships on compulsory social insurance are included into the subject of labour law (Article 1 of the Labour Code of the Russian Federation), just as other relationships directly related to labour. Most of the persons insured in the social insurance system covering temporary disability and maternity are those who work under employment contracts (Art. 2 of the Federal Law 'On Compulsory Social Insurance in Case of Temporary Disability and Maternity"7). A similar right is enshrined in the Federal Law 'On Compulsory Medical Insurance in the Russian Federation'8: the people insured work under employment contracts (Art. 10). The compulsory social insurance covering industrial accidents and occupational illnesses applies to persons working on an employment contract concluded with an insurance company (Art. 5 of the Federal Law 'On Compulsory Social Insurance Against Industrial Accidents and Occupational Illnesses' ${ }^{\prime}$ ).

It is necessary to highlight the compulsory pension insurance, which is primarily applied to persons working under an employment contract (Art. 7 of the Federal Law 'On Compulsory Pension Insurance in the Russian Federation' ${ }^{10}$ ). At present, the size of pensions is closely linked to duration of employment and size of the employee's salary ${ }^{11}$.

The availability of various types of social insurance within the framework of labour relationships is aimed at meeting the need for safety, which forms a sense of security among employees and provides support in cases of social risk.

A significant number of citizens spend more than a third of their conscious life at the workplace, contributing to the development of society. The right to the highest attainable health standards is generally recognized; without them, a person can neither work and be useful to society, nor achieve his own wellbeing. Risking an employee's life in the workplace results in a loss for productive employment and a violation of socio-economic development. The right of employees to the protection of their health and life in the workplace is not only a matter for labour law but is also considered a basic human right ${ }^{12}$.

Therefore, we can say that an employee not only feels the need for material resources, but also for the creation of favourable, decent conditions in the workplace in accordance with generally accepted norms and standards, which provides him/her with the opportunity to satisfy the need for safety.

The need to satisfy the afore-mentioned socially significant needs led to the emergence of labour law as an independent branch. No other branch of law allows the overwhelming majority of the working-age population to satisfy their socially significant needs connected with their livelihood.

It should be noted that today, more and more often, satisfaction with work in terms of its content, pay, conditions, opportunity to combine it with family responsibilities, vocational training and retraining, which is the basis for the concept of work life quality, has begun to be included in the needs of a working person. The concept of quality of work life appeared in the 1970s. The quality of an employee's work life is defined as the degree to which his/her basic needs are satisfied, including not only the need for material benefits, but also the need for the nature and content of labour, work conditions, and the need to realize the employee's capabilities. The quality of an employee's work life is considered as one of the components of the quality of life, reflecting not only the level at which a person's basic spiritual and material needs are met, but also the characteristics of the person's labour activity, including the conditions for performing work, complexity of work, its duration, use of the employee's labour potential, the attitude of the employer and colleagues towards him/her, and other parameters. 'In the last decades of the twentieth century, the quality of work life has become increasingly closely linked to a healthy working and ecological environment, social protection from occupational and technological risks, becoming synonymous with higher social standards for the population's well-being, stability in life, thereby acquiring the social security and distributive connotations of a 'welfare society' (Roik, 2017: 34).

\footnotetext{
${ }^{7}$ Federal Law No. 255-FZ of December 29, 2006 'On Compulsory Social Insurance in Case of Temporary Disability and Maternity'.

${ }^{8}$ Federal Law No. 326-FZ of November 29, 2010 ‘On Compulsory Medical Insurance in the Russian Federation'.

${ }^{9}$ Federal Law No. 125-FZ of July 24, 1998 'On Compulsory Social Insurance Against Industrial Accidents and Occupational Illnesses'.

${ }^{10}$ Federal Law No. 167-FZ of December 15, 2001 'On Compulsory Pension Insurance in the Russian Federation.

${ }^{11}$ Federal Law No. 400-FZ of December 28, 2013 'On Non-Contributory Pensions'.

${ }^{12}$ International Labour Office (2009) Safe Work is the Right of Everyone. ILO report for World Day for Safety and Health at Work. Available from: http://www.ilo.org/ [Accessed 20 February 2021].
} 
We believe that improving the quality of work life should become a priority task for the state, and labour legislation can play a decisive role in solving this problem (Golovina, Kuchina \& Serova, 2019:715719). It seems that the reflection of this role should be enshrined in Art. 1 of the Labour Code of the Russian Federation by clarifying one of the goals of the labour legislation - to improve the quality of the work life of citizens. By contributing to the improvement of work life quality, the labour law once again proves its high social value.

It is vital to note that labour law regulations make it possible to satisfy the socially significant needs not only of the employee, but also of the employer. As N. G. Aleksandrov wrote, labour requires management to ensure its appropriate use in accordance with the objectives of the enterprise. The function of the labour process management is necessary wherever the labour process does not take place in the form of individual independent labour. Labour management, since it stems from the general nature of any non-individual labour, is a characteristic feature of labour relationships in general (1948: 125). Only within the framework of the labour relationships can the employer comprehensively manage the labour process, monitor it, and require employees to obey the established order.

The needs of the employee and the employer are closely linked, their balanced implementation is of fundamental importance for ensuring and realizing not only the socially significant needs of the parties in labour relationships, but also for maintaining public welfare in society. In this sense, a balanced implementation of needs of both parties of labour law is ideal. It is no coincidence that the Constitutional Court of the Russian Federation emphasizes the demand to establish a balance of constitutional rights and freedoms, fair coordination of the rights and legitimate interests of parties of an employment contract, which is a necessary condition for harmonizing labour relationships in the Russian Federation ëas a social legal state ${ }^{13}$.

A. I. Protsevskiy pointed out 'the invisible presence of the state when citizens enter employment relationships, which is expressed in the establishment of rules of conduct for both parties of an employment contract' (1972: 66). Moreover, 'a review of labour organization forms known to modern science, shows that the legal regulation of labour relationships appears with the emergence of hired labour and intensifies as it spreads' (Kuzmenko, 2005: 53). The state implements the legal regulation of labour relationships, based both on the necessity to satisfy the socially important needs of employees and employers, and on the needs of society. 'The very existence of objective law makes sense only insofar as it reflects the real interests of the participants in public relationships and the society as a whole' (Khokhlov, 1996, I: 252). Moreover, labour is an essential condition for the development of society and economy, and the procedure and provisions for its application directly affect the rate of economic growth.

This does not diminish the importance of other branches of law that have a direct impact on the provision of social peace, particularly the law of social security. At the same time, the impact of labour law regulations on the formation and maintenance of social peace is more effective, which confirms the social value of labour law as an independent branch of law.

\section{Conclusion}

The analysis in this study confirms that in modern society, labour law as an independent branch of law is, as it was during its formation, still a social value. The social value of labour law has to do with the fact that it is necessary for both an individual and society as a tool that satisfies their needs and interests.

Labour law is based on the most important human value - labour offered by one party (employee) to receive remuneration, which can satisfy needs and livelihood, while the other party (employer), in managing the labour process, realizes its goals and objectives. The state, in its turn, in implementing the legal regulation of labour relationships, follows the public needs in order to support social peace.

To establish social peace in society, the state needs to create conditions that allow the employee to meet his/her socially significant needs (which are based on basic human needs) at least to a minimum, through

${ }^{13}$ Ruling of the Constitutional Court of the Russian Federation No. 3-P of March 15, 2005 'Examination of the Constitutionality of the Provisions under Paragraph Two of Article 278 and Article 279 of the Labour Code of the Russian Federation and the Sub-paragraph Two under Paragraph Four of Article 69 of the Federal Law 'On Joint-Stock Companies' in Respond to Requests of the Volkhov Municipal Court of the Leningrad region, Oktyabrskiy District Court of the City of Stavropol and to Petitions of a Number of Citizens'. 
the implementation of labour law; that is, the establishment of social benefits and state guarantees safe work conditions, minimum wages, maximum limits for working hours and minimum limits for hours of rest, and measures aimed at creating decent working conditions and improving the quality of work life.

On the other hand, the state takes care of the socially important needs of employers, providing them with incentives for implementing regulatory, directive and disciplinary power, in particular the right to regulate labour relationships in the form of local rulemaking, determine the mode of work and rest, establish remuneration systems, etc.

As time goes by, the needs of an individual and society can change and, accordingly, the labour law is forced to transform and be integrated into the updated system of values. Thus, the digitalization of the economy made it necessary to include a new chapter 49.1 in the Labour Code of the Russian Federation, which establishes regulation options for remote employees. The coronavirus infection COVID-19 pandemic, which provoked the need for social distancing to preserve the health and life of the public, has become a trigger for developing the institution of remote labour, whose norms were no longer in line with the public needs for compliance with anti-epidemiological rules. The updated chapter 49.1 of the Labour Code of the Russian Federation now includes several models for distance (remote) working and various methods for registering it, in addition to establishing the necessary guarantees for employees when transferring to remote work.

It would not be an exaggeration to conclude that labour law ranks first among the legal branches directly affecting society. It is labour law that regulates the relations within which social wealth is created - material and spiritual values utilized by everyone (Snigireva, 2017: 151-152). This also confirms the social value of labour law not only for individuals (parties of labour relationships), but also for society as a whole.

It seems that studying the socially significant needs of the subjects of law, which is inextricably linked with the level of social development, can contribute to the development of labour law and legislation, since it opens up new milestones for improving approaches to the legal regulation of labour and other relationships directly related to them.

Labour law in Russia as an independent branch will retain its social value as long as it fully complies with modern, objective, socially significant needs of employees and employers, and can coordinate them.

G. V. Maltsev, a well-known scientist not only in the field of jurisprudence, but also in the philosophy and sociology of law, noted that 'the law that does not have a convinced ally to whom it addresses its norms is weak and insignificant' (2011: 121). Consequently, if laws do not reflect the vital, basic needs of individuals (in a generalized form), social groups and society, they lose their regulatory function. The fact that people comply with law has, in essence, a simple explanation: this suits their needs (Maltsev, 2011: 267).

It could be argued that the satisfaction of socially important needs is not the exclusive prerogative of labour law. Of course, in all branches of law, those fundamental human rights are fixed, whose implementation is aimed at satisfying some socially significant needs. However, perhaps, it is the labour law, through which the basic physiological needs of a person can be better satisfied. Without satisfying these needs, neither maintaining a livelihood, nor the manifestation of higher social needs are possible. The foregoing allows us to conclude that the implementation of fundamental human rights and freedoms in the most concentrated form is contained in the labour law, rather than in other branches of law, whose regulations, as a rule, are aimed at realizing one of the fundamental human rights. This evokes the specific social value of the labour law.

\section{References}

Aleksandrov, N. G. (1948) Trudovoe pravootnoshenie [Labour Relationship]. Moscow: Publishing house for legal literature of the USSR Ministry of Justice. (in Russian).

Alekseev, S. S. (2019) Sotsial'naya tsennost' prava v sovetskom obshchestve [Social Value of Law in the Soviet Society]. Yekaterinburg: Humanities University. (in Russian).

Berezovskaya, E.V. (2013) About Social Value of Law in Civil Society. Bulletin of East Siberian Institute of the Russian Federation Ministry of Interior Affairs. 66 (3), 84-89. (in Russian).

Chinkin, I. V. (2010) Vzaimosvyaz' truda i potrebnostei v dinamike obshchestvennoi zhizni cheloveka [Interaction of Labour and Needs in Dynamics of Human Public Life]. Extended abstract of Ph.D. thesis. Altai State Pedagogical Academy, Barnaul. (in Russian). 
Golovina, S. Yu., Kuchina, Yu. A. \& Serova, A. V. (2019) Increasing the Quality of Work life: Modern Labor Legislation's Strategic Task. Humanities and Social Sciences: Novations, Problems, Prospects, Advances in Social Science, Education and Humanities Research, volume 333. Dordrecht, Atlantis Press, pp. 715-719. https://dx.doi.org/10.2991/hssnpp-19.2019.136.

Hegel, G. W. F. (1928) Lectures on History Philosophy. Translated from German by Woden, A. M. Saint Petersburg, Nauka. (in Russian).

Hegel, G. W. F. (1934) Philosophy of Law. Vol. 7. In: Hegel, G. W. F. Works Collection in 14 vol. Translated from German by Stolpner, B. G. Moscow, Saint Petersburg, Sotsegiz. (in Russian).

Ihering, R. (1881) The Purpose in Law: in 2 volumes. First volume. Translated from German by Deryuzhskiy, N. F., Muravyev, N. V., Saint Petersburg, Publication by N. V. Muravyev. (in Russian).

Kerimov, D. A. (1972) Filosofskie problemy prava [Philosophical Problems of Law]. Moscow, Mysl. (in Russian).

Khokhlov, Ye. B. (ed.) (1996) Kurs rossiiskogo trudovogo prava: $v 3$ t. T. 1: Obshchaya chast' [Course of Russian Labour Law: in 3 vol., Vol. 1: General Part]. St. Petersburg, Publishing house of the St. Petersburg State University. (in Russian).

Khoklov, E. B. (2013) Istoriya truda v kontekste khozyaistvennykh, politicheskikh i mental'nykh system. T.1 [History of Labour in the Context of Administrative, Political and Mental Systems. Vol. I]. In: Khokhlov, E. B. History of Labour and Labour Law in 3 vol. Saint Petersburg, Publishing house of the Saint Petersburg State University. (in Russian).

Khudyakova, S., Bryukhina, E. \& Novikova, N. (2011) Pravo na trud i pravo na obrazovanie $v$ sovremennoi Rossii. Vzaimodeistvie yuridicheskikh garantii [Rights to work and Education in Modern Russia. Interaction of Judicial Safeguards]. Saarbrucken, LAP Lambert Academic Publishing. (in Russian).

Kuzmenko, A. V. (2005) Predmet trudovogo prava Rossii: opyt sistemno-yuridicheskogo issledovaniya [Subject of Labour Law of Russia: Experience of Systematic Legal Research]. Saint Petersburg, Publishing house of R. Aslanov 'Legal Center Pres'. (in Russian).

Maltsev, G. V. (2011) Sotsial'nye osnovy prava [Social Foundations of Law]. Moscow, Norma: INFRA-M. (in Russian).

Martseva, L. M. (2002) Trud v kontekste rossiiskoi tsivilizatsii. Sotsial'no-filosofskii aspekt: Monografiya [Labour in Context of Russian Civilization. Socio-Philosophical Aspect: Monograph]. Omsk, Omsk State Transport University. (in Russian).

Maslow, A. (2008) Motivation and Personality. Translated from English. 3rd ed.,Saint Petersburg, Piter. (in Russian).

Nikiforova, N. N. (1983) Social Function of Labour Law. Pravovedeniye. (3), 74-78.

Ozerov, I. Kh. (1904) Stat'i po rabochemu voprosu [Articles Related To Labour Issue]. In: Ozerov, I. Kh. From Life of Labour: Collection of articles in 2 vol. Moscow, D. S. Gorshkov. (in Russian).

Plato (2015) Opening letter by E.N. Trubetskoy. Commented by V.F. Asmus. Notes by A.A. TakhoGodi. In: Plato. State. Translated from Ancient Greek by Yegunov, A. N. Moscow, Akademicheskiy prospekt. (in Russian).

Protsevskiy, A. I. (1972) Metod pravovogo regulirovaniya trudovykh otnoshenii [Method of Legal Regulations for Workplace Relations]. Moscow, Yuridicheskaya Literatura. (in Russian).

Roik, V. D. (2017) Trud i kachestvo trudovoi zhizni: praktika i teoriya regulirovaniya $v$ zapadnykh stranakh i Rossii: monografiya [Labour and Work life Quality: Practice and Control Theory in Western Countries and in Russia: Monograph]. Moscow, Prospekt. (in Russian).

Slezinger, G. E. (1996) Trud v usloviyakh rynochnoi ekonomiki [Labour in the Market Economy Environment]. Moscow, INFRA-M. (in Russian).

Smith, A. (1908) Issledovanie o bogatstve narodov [An Inquiry into the Nature and Causes of the Wealth of Nations]. Translated from English by Schepkina, M. P. \& Kaufman A. A., 2 ${ }^{\text {nd }}$ ed., Saint Petersburg, M. N. Prokopovich. (in Russian).

Smith, R. (2013) International Protection of Human Rights. Translated from English. Minsk, Yunipak. (in Russian).

Snigireva, I. O. (2017) Labour Law in Social State. From Social Rights to Social Law (VII Pashkov readings): collection of articles on materials of the International Research-to-Practice Conference, 
Saint Petersburg State University, 24-26 February 2016, Saint Petersburg, Centre for Social and Legal Technologies, pp. 149-156. (in Russian).

Yavich, L. S. (1985) Sushchnost' prava [Essence of Law]. Saint Petersburg, Publishing house of the Leningrad State University. (in Russian).

Zdravomyslov, A. G. (1977) Zhiznennye potrebnosti trudyashchikhsya i ikh udovletvorenie v usloviyakh razvitogo sotsializma [Workers' Basic Needs and Their Satisfaction in Conditions of Developed Socialism]. Moscow, Znanie. (in Russian).

\section{Information about the authors}

Svetlana Yu. Golovina - Doctor of Juridical Sciences, Professor, Head of the Labour Law Department, Ural State Law University, Yekaterinburg, Russia (54 Kolmogorova str., Yekaterinburg, 620034, Russia; e-mail: golovina.s@inbox.ru).

Yulia V. Ivanchina - Doctor of Juridical Sciences, Associate Professor, Professor of the Labour Law Department, Ural State Law University, Yekaterinburg, Russia (54 Kolmogorova str., Yekaterinburg, 620034, Russia; e-mail: julia.ivanchina@gmail.com).

(C) S. Yu. Golovina, 2021

(c) Yu. V. Ivanchina, 2021

Date of Paper Receipt: May 3, 2021

Date of Paper Approval: June 12, 2021

Date of Paper Acceptance for Publishing: July 26, 2021 